\title{
Fermentative characteristics and nutritional value of sugarcane silage added with two types of urea
}

\author{
Características fermentativas y valor nutricional del ensilaje de caña de azúcar con adición de dos tipos \\ de urea
}

\author{
Características fermentativas e valor nutricional da silagem de cana-de-açúcar aditivada com dois tipos \\ de ureia
}

\author{
Wagner Sousa-Alves $^{1}$ iD; João-Paulo S Rigueira*2 ${ }^{*}$; ; Marielly M Almeida-Moural ${ }^{1}$ iD; Diego L S de-Jesus ${ }^{1}$ iD; Flávio P

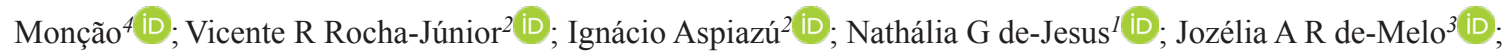 \\ Marcos F P da-Silva ${ }^{3}$ iD.
}

\author{
${ }^{1}$ Pós Graduação em Zootecnia, Brasil. \\ ${ }^{2}$ Universidade Estadual de Montes Claros, Janaúba, Brasil. \\ ${ }^{3}$ Curso de Graduação em Zootecnia da Universidade Estadual de Montes Claros. \\ ${ }^{4}$ Bolsista de Pós Doutorado da Pós Graduação em Zootecnia da Universidade Estadual de Montes Claros.
}

To cite this article:

Sousa-Alves W, Rigueira JPS, Almeida-Moura MM, de-Jesus DLS, Monção FP, Rocha-Júnior VR, Aspiazú I, de-Jesus NG, de-Melo JAR, da-Silva MFP. Fermentative characteristics and nutritional value of sugarcane silage added with two types of urea. Rev Colomb Cienc Pecu 2020; 33(3): 182-194. DOI: https://doi.org/10.17533/udea.rccp.v33n3a02

\begin{abstract}
Background: Dry matter (DM) loss is high in sugarcane silage due to its high content of soluble carbohydrates which favors yeast growth and ethanol production, thus reducing the nutritional value of the preserved forage. Objective: To determine the effect of adding two types of urea at two concentration levels to sugarcane silage on the nutritional value and fermentative characteristics of the silage. Methods: A completely randomized $2 \times 2+1$ factorial design was used, based on two types of urea (conventional and protected), two urea concentration ( 0.5 and $1.0 \%$ of the natural matter), and a control (sugarcane silage with no additives). Six replicates were used. The mixture was placed in PVC silos and opened after 60 days. Results: There was no difference in DM content or effluent losses by the addition of urea. In regards to neutral detergent fiber, acid detergent fiber, and lignin, decreased levels were observed compared to the control, regardless of urea type. Urea type and concentration had an effect on ammoniacal nitrogen content, with higher values for conventional urea, but not affecting the $\mathrm{pH}$. The addition of urea to sugarcane silage reduced gas losses and raised the levels of crude protein, ether extract, and effective degradability. Conclusion: Adding protected or conventional urea at $1 \%$ of natural matter at the time of sugarcane ensiling reduces gas losses and improves nutritional composition of the silage.
\end{abstract}

Keywords: conservation; ensilage; fermentation; forage; fiber; losses; protein; rumen degradability; ruminant; sugarcane; silage; urea.

Received: May 22, 2018; accepted: November 25, 2019

*Corresponding Author. Avenida Reinaldo Viana, 2630, Bico da Pedra, Janaúba, Minas Gerais, Brasil.

E-mail: jpzootecnia@hotmail.com 


\section{Resumen}

Antecedentes: La caña de azúcar ensilada presenta una elevada pérdida de materia seca (MS) debido a su alto contenido de carbohidratos solubles que favorece el crecimiento de levaduras y la producción de etanol, reduciendo así el valor nutricional del ensilado. Objetivo: Determinar el efecto de dos tipos de urea en dos concentraciones sobre las características fermentativas y el valor nutricional del ensilaje de caña de azúcar. Métodos: Se utilizó un diseño completamente al azar, en esquema factorial $2 \times 2+1$, basado en dos tipos de urea (común o protegida), dos concentraciones de urea $(0,5$ y $1,0 \%$ de la materia natural) y un control (ensilaje de caña de azúcar sin aditivos). Se utilizaron seis réplicas de cada tratamiento. El material fue ensilado en silos de PVC, los que fueron abiertos después de 60 días. Resultados: No hubo diferencia en el contenido de MS o en las pérdidas por efluentes con la adición de urea. En relación a la fibra detergente neutra, fibra detergente ácida y lignina, se observó disminución de éstos con respecto al control, independientemente del tipo de urea. Se observó un efecto de la concentración y del tipo de urea para el contenido de nitrógeno amoniacal, con mayores valores para la urea común, pero sin efecto sobre el pH. La adición de urea en el ensilado de caña redujo las pérdidas por gases y elevó los niveles de proteína bruta, extracto etéreo y degradabilidad efectiva. Conclusión: La adición de urea común o protegida, al 1\% de materia natural, al inicio del ensilaje de caña de azúcar reduce las pérdidas por gases y mejora la composición nutricional del ensilaje.

Palabras clave: caña de azúcar; conservación; degradabilidad ruminal; ensilado; ensilaje; fermentación; fibra; forraje; pérdidas; proteína; rumiante; urea.

\section{Resumo}

Antecedentes: A ensilagem de cana-de-açúcar sem aditivos apresenta elevada perda de matéria seca (MS) devido ao alto teor de carboidratos solúveis, favorecendo o crescimento de leveduras e produção de etanol, reduzindo assim o valor nutricional da forragem conservada. Objetivo: Determinar o efeito do tipo de ureia (comun ou protegida) e diferentes concentrações nas características fermentativas e valor nutritivo das silagens de cana-de-açúcar. Métodos: Utilizou-se um delineamento inteiramente casualizado em esquema fatorial 2 × $2+1$, sendo dois tipos de ureia (comun ou protegida), e duas concentrações ( 0,5 e $1,0 \%$ com base na matéria natural) mais o controle (silagem exclusiva de cana-de-açúcar); com seis repetições. O material foi ensilado em silos de PVC e abertos após 60 dias. Resultados: Não houve diferença no teor de MS e nas perdas por efluentes com adição da ureia. Em relação à fibra em detergente neutro, fibra em detergente ácido e lignina observou-se diminuição destes em relação ao controle, independente do tipo de ureia. Observou-se efeito das concentrações e do tipo de ureia para o teor de nitrogênio amoniacal, com maiores valores para a ureia comum, porém sem efeito no pH. A adição de ureia na ensilagem de cana reduziram as perdas por gases e elevaram os teores de proteína bruta, extrato etéreo e degradabilidade efetiva. Conclusão: O uso de 1\% de ureia, independente do tipo, promove um incremento no valor nutricional da silagem de cana-de-açúcar e reduz as perdas por gases.

Palavras-chave: cana-de-açúcar; conservação; degradabilidade ruminal; ensilagem; fermentação; fibra; foragem; perdas; proteína; ruminante; uréia. 


\section{Introduction}

The use of sugarcane (Saccharum spp L.) in the in natura form to feed cattle is an established practice among Brazilian cattle ranchers. However, the daily cutting of sugarcane is burdensome and causes logistical and operational problems owing to the daily demands of labor. Thus, sugarcane is generally used as silage to feed cattle (Rigueira et al., 2018). However, when sugarcane is ensiled, it presents a fermentative pattern characterized by high ethanol production and loss of soluble carbohydrates, which is mediated by yeasts; reducing its nutritional value and losing dry matter (DM) (Moreira et al., 2014; Roth et al., 2016).

Urea is oftenused as an additive to silage. This is based on the transformation of urea into ammonia, which reacts with water to form ammonium hydroxide, raising the $\mathrm{pH}$, and inhibiting the metabolism of undesirable microorganisms such as yeasts (Kung Junior et al., 2003). The buffering effect of ammonium hydroxide on silage $\mathrm{pH}$ can be advantageous, although this depends on the extent to which it is able to delay $\mathrm{pH}$ decrease. If the buffering effect is moderate, then there is greater competition between lactic acid bacteria and yeasts, since the latter are predominant in fermentation at $\mathrm{pH}$ values below 4. However, if the buffering effect is large, then development of undesirable microorganisms that act at higher $\mathrm{pH}$ is favored, causing forage deterioration.

Recently, a product termed 'protected urea' has been developed. It generates a controlled release of ammonia and reduces the buffering effect caused by conventional urea in addition to allowing higher concentration to be used at the time of ensilage.

Therefore, the objective of this work was to compare the fermentative characteristics of adding protected or conventional urea to sugarcane silage and to assess the nutritive value of the silage.

\section{Materials and methods}

\section{Ethical considerations}

The experiment was approved by the Ethics Committee for Animal Experimentation of Universidade Estadual de Montes Claros (number 155/2018). The study was performed at the Departamento de ciências agrárias da Universidade Estadual de Montes Claros (UNIMONTES), Campus Janaúba-MG, Brazil (GPS coordinates: latitude $15^{\circ} 52^{\prime} 38^{\prime \prime} \mathrm{S}$, longitude $43^{\circ} 20^{\prime} 05^{\prime \prime} \mathrm{W}$ ).

\section{Experimental design}

A completely randomized $2 \times 2+1$ factorial design was used, based on two types of urea (conventional and protected), two urea concentrations ( 0.5 and $1 \%$ of the natural matter), and a control (sugarcane silage with no additives). Six replicates were used.

\section{Procedures}

The sugarcane variety used was IAC 862480 , obtained from the experimental farm of UNIMONTES. The forage was cut manually. One year after the last cut, the stalks were chopped using a stationary forage harvester (Nogueira, São João da Boa Vista, SP, Brazil) with the knives adjusted to obtain 1 to $2 \mathrm{~cm}$ particle size. Four $20 \mathrm{~kg}$ piles of fresh sugarcane were harvested, protected or conventional urea was added at the desired proportions, and then the mixture was homogenized.

The silages were prepared in PVC silos, $50 \mathrm{~cm}$ in height and $10 \mathrm{~cm}$ in diameter, with a Bunsen valve. At the bottom of the silos, 0.4 $\mathrm{kg}$ of dry sand was added to drain the effluents, and a layer of foam to prevent contact between the silage and the sand. The experimental set, consisting of silo plus a lid, sand, and foam, was weighed to obtain the empty weight of the silo. Subsequently, the mixtures to be ensiled were placed into the silos and compacted to a density of $550 \mathrm{~kg} \mathrm{~m}^{-3}$ (Ruppel et al., 1995). The silos were sealed, stored at room temperature $\left(25^{\circ} \mathrm{C}\right)$, and opened only after 60 days. Before opening, the silos were reweighed to quantify gas losses. 
After removal of the silage, the experimental set containing silo plus lid, sand, and foam were reweighed to quantify the produced effluent (Jobim et al., 2007).

After the silage was removed from the silos, it was homogenized; one part was pressed with a hydraulic press $\left(\right.$ Bovenau $^{\circledR}$, Rio do Sul, SC, Brazil) to extract silage juice. The $\mathrm{pH}$ of this liquid was determined using a potentiometer (Tecnal ${ }^{\circledR}$, Piracicaba, SP, Brazil), and the level of ammoniacal nitrogen $\left(\mathrm{N}-\mathrm{NH}_{3}\right)$ was estimated by distillation with magnesium oxide and calcium chloride using a boric acid receptor solution and titration with $0.1 \mathrm{~N}$ hydrochloric acid (AOAC, 1980). The remainder of the silage was dried in a forced ventilation oven at $55^{\circ} \mathrm{C}$ for $72 \mathrm{~h}$ and ground in a mill (Thomas Model 4 Wiley; Thomas Scientific, Swedesboro, NJ, USA) with $1 \mathrm{~mm}$ sieve screens for chemical analysis, and 5 $\mathrm{mm}$ for in situ incubation.

Analyses were carried out according to the analytical procedures of the National Institute of Science and Technology in Animal Science (INCT-CA; Detmann et al., 2012). Dry matter (DM), crude protein (CP), ether extract (EE), neutral detergent fiber (NDF), acid detergent fiber (ADF), and lignin were assessed.

To evaluate ruminal degradation kinetics, four $450 \pm 50 \mathrm{~kg}$ crossbred steers were used. All the animals had a gastric cannula. The animals received $3.0 \mathrm{~kg}$ concentrate in two equal portions in the morning and afternoon, as well as diet based on cane silage. The in situ degradability technique described by Casali et al. (2009) was performed using $7.5 \times 15 \mathrm{~cm}$ non-woven fabric bags with an approximate porosity of $60 \mu \mathrm{m}$. The number of samples was determined from the ratio of $20 \mathrm{mg}$ DM cm$~^{-2}$ of bag surface area (Nocek, 1988).

The bags were placed in $20 \times 30 \mathrm{~cm}$ fillet bags along with $100 \mathrm{~g}$ lead weights. The fillet bags were tied with a nylon thread, leaving a length of $1 \mathrm{~m}$ so that the bags could move freely in the solid and liquid phases of the rumen. The fillet bags were then deposited in the ventral sac region of the rumen with the end of the nylon thread remaining attached to the cannula for 0 , $6,12,24,48,72,96,120$ and $144 \mathrm{~h}$ in reverse order, i.e., starting with the duration of $144 \mathrm{~h}$. The $0 \mathrm{~h}$ time samples were inserted into the rumen for $5 \mathrm{~min}$. Subsequently, all samples were collected and washed in ice water to stop ruminal fermentation. Afterward, the samples were placed in greenhouses at $55^{\circ} \mathrm{C}$ for 72 hours and then cooled in a desiccator and weighed.

The residues remaining in the non-woven fabric bags following collection from the rumen were analyzed for DM and NDF contents. The percent degradation was calculated by the proportion of food remaining in the bags after ruminal incubation, and NDF was analyzed according to the methods proposed by Van Soest et al. (1991) without the use of $\alpha$-amylase. The obtained data were adjusted to a non-linear regression by the Gauss-Newton method (Neter et al., 1985) using the SAS software (SAS, 2008), according to the equation proposed by Ørskov \& Mcdonald (1979): $Y=a+b\left(1-e^{-c t}\right)$, where $\mathrm{Y}=$ is the cumulative degradation of the nutritional component analyzed after time $\mathrm{t}$; a $=$ the degradation curve intercept when $\mathrm{t}=0$, which corresponds to the water-soluble fraction of the analyzed nutrient component; $b=$ the degradation potential of the water-insoluble fraction of the analyzed nutrient component; $\mathrm{a}+\mathrm{b}=$ the degradation of the analyzed nutritional component when time is not a limiting factor; $\mathrm{c}=$ the rate of degradation per fermentative action of $b$; and $t=$ incubation time.

Once calculated, the $a, b$, and c coefficients were applied to the equation proposed by Ørskov \& McDonald (1979): $\mathrm{ED}=\mathrm{a}+(\mathrm{bxc} / \mathrm{c}+\mathrm{k})$, where $\mathrm{ED}=$ is the effective degradability of the nutritional component, and $\mathrm{k}=$ the feed passage rate. The particle passage rate through the rumen was estimated to be $5 \% \mathrm{~h}^{-1}$, as suggested by AFRC (1993).

\section{Statistical analysis}

A completely randomized design in a 2 x $2+1$ factorial arrangement with two urea types (conventional and protected) in two 
concentrations $(0.5$ and $1 \%$ of the natural matter) plus one control treatment (sugarcane silage with no additives) and six replicates was used for fermentation traits and chemical composition variables. The data were submitted to analysis of variance using PROC GLM of SAS, version 9.2 (SAS Institute, Inc., Cary, NC, USA). When the "F" test was significant for the treatments, urea concentrations and types were analyzed by $t$ test. For all tests, $\alpha=0.05$ was used. The mathematical model used was Yijk $=\mu+\tau \mathrm{i}+\operatorname{doses} \mathrm{j}+\tau \mathrm{i} \mathrm{x}$ doses $\mathrm{j}+$ cijk, where: Yijk is the observation ijk; $\mu$, the overall mean; $\tau \mathrm{i}$, the effect of the treatment urea types, with $i=1$ and 2 ; concentrations, the effect of urea concentrations; the random effect $\mathrm{k} ; \tau \mathrm{i} \mathrm{x}$ concentrations $j$, the interaction effect of urea types $\mathrm{i}$ and concentrations $\mathrm{j}$; cijk is the random error with mean 0 and variance $\sigma^{2}$.

For the in situ degradability variables, a splitplot randomized complete block was used, with five treatments (plots), nine incubation times (subplots), and four blocks. The different animal weights were the blocking factor. Data were tested via analysis of variance and regression using the MIXED procedure of SAS, at $\alpha=0.05$, according to the model: Yijk $=\mu+\tau i+$ Time $j+$ $\tau \mathrm{i} x$ Time $\mathrm{j}+\varepsilon \mathrm{ijk}$, where: Yijk is the observation $\mathrm{ijk} ; \mu$, the overall mean; $\tau \mathrm{i}$, the fixed effect of the treatment applied to the plot, with $i=1,2,3$, 4 and 5; Time, fixed effect of incubation time $\mathrm{j}$ to subtract; the random effect of animal k; Tix Time $\mathrm{j}$, the interaction effect of treatment $\mathrm{i}$ and time $\mathrm{j}$; cijk, the random error with mean 0 and variance $\sigma^{2}$. The treatment means were compared to the control by Dunnett's test $(\alpha=0.05)$.

\section{Results}

The DM contents of the silages did not differ with the addition of urea. The $\mathrm{pH}$ values were within a suitable range for forage conservation, with a difference only for the silage with $1 \%$ conventional urea compared with that of the control silage $(p<0.05$; Table 1$)$.

Table 1. Fermentation profile of sugarcane silage supplemented with two types of urea and two concentrations.

\begin{tabular}{|c|c|c|c|c|c|c|c|c|c|}
\hline \multirow{2}{*}{ Concentrations } & \multicolumn{2}{|c|}{ Urea } & \multirow[b]{2}{*}{ Mean } & \multirow[b]{2}{*}{ Control } & \multirow[b]{2}{*}{ SEM } & \multicolumn{4}{|c|}{ p-value ${ }^{1}$} \\
\hline & protected & conventional & & & & Type & Dose & TxC & AxCTL \\
\hline \multicolumn{5}{|c|}{$\mathrm{pH}$} & 0.217 & NS & NS & NS & $*$ \\
\hline $0.5 \%$ & 3.41 & 3.48 & & \multirow{2}{*}{3.37} & & & & & \\
\hline $1.0 \%$ & 3.47 & $3.50^{*}$ & & & & & & & \\
\hline \multicolumn{5}{|c|}{$\mathrm{N}-\mathrm{NH} 3 / \%$ total nitrogen } & 0.602 & $* *$ & $* *$ & NS & $*$ \\
\hline $0.5 \%$ & 14.06 & 16.58 & $15.32^{\mathrm{B}}$ & \multirow{3}{*}{11.87} & & & & & \\
\hline $1.0 \%$ & $15.02 *$ & $22.21 *$ & $18.61^{\mathrm{A}}$ & & & & & & \\
\hline Mean & $14.54^{\mathrm{b}}$ & $19.39^{\mathrm{a}}$ & & & & & & & \\
\hline \multicolumn{5}{|c|}{ Gas losses $\left(\mathrm{kg} \mathrm{t}^{-1}\right)$} & 0.807 & NS & NS & NS & $* *$ \\
\hline $0.5 \%$ & $7.13^{*}$ & $7.78^{*}$ & & \multirow{2}{*}{13.55} & & & & & \\
\hline $1.0 \%$ & $7.03^{*}$ & $7.13^{*}$ & & & & & & & \\
\hline \multicolumn{4}{|c|}{ Efluent loss $\left(\mathrm{kg} \mathrm{t}^{-1}\right)$} & & 0.674 & NS & NS & NS & NS \\
\hline $0.5 \%$ & 29.22 & 29.14 & & \multirow{2}{*}{25.81} & & & & & \\
\hline $1.0 \%$ & 25.46 & 28.13 & & & & & & & \\
\hline
\end{tabular}

\footnotetext{
${ }^{1}$ Type, effect of urea type; Concentration, effect of urea concentration; TxC: interaction effect between type and concentration of urea; AxCTL: effect of the additive compared to the control.

$*$ and $* *$ significant at the level of 5 or $1 \%$ significance, respectively.

* Means followed by an asterisk differ from the control by Dunett's test $(\mathrm{p}<0.05)$.

Means followed by different superscript upper-case letters $\left({ }^{A}, \mathrm{~B}\right)$ within the same column, and different superscript lower-case letters $\left({ }^{a}, b\right)$ within the same row, are significantly different by the t test $(p<0.05)$.

SEM - standard error of the mean.
} 
The treatments with $1 \%$ urea had a higher fraction of $\mathrm{N}_{-} \mathrm{NH}_{3}$ than both the control and the $0.5 \%$ treatment $(p<0.05)$. In relation to urea type, conventional urea showed higher N-NH3 fraction than that of protected urea $(p<0.05)$. Effluent losses were not influenced by the addition of urea $(p>0.05)$. Lower gas losses were observed in all urea treatments when compared with the control silage $(\mathrm{p}<0.05$; Table 1$)$.

There was a significant interaction between dose and type of urea for crude protein $(p<0.05)$, and all treatments differed from the control $(p<0.05)$. The EE content was higher for silages with $1 \%$ urea $(\mathrm{p}<0.05)$. Regarding the different types of urea, protected urea showed the highest levels $(p<0.05$; Table 2$)$. Reductions in NDF, ADF, and lignin were observed in the fibrous fraction compared with that in the control treatment $(p<0.05$; Table 2$)$. All treatments differed from the control for NDF $(p<0.05)$. For ADF, only silage with $1 \%$ conventional urea differed from the control; for lignin, all treatments with $1 \%$ urea, regardless of type, differed from the control. There was no interaction effect between type and dose of urea $(\mathrm{p}>0.05)$.

Table 2. Chemical composition of sugarcane silage supplemented with two types of urea and two concentrations.

\begin{tabular}{|c|c|c|c|c|c|c|c|c|c|}
\hline \multirow{2}{*}{ Concentrations } & \multicolumn{2}{|c|}{ Urea } & \multirow[b]{2}{*}{ Mean } & \multirow[b]{2}{*}{ Control } & \multirow[b]{2}{*}{ SEM } & \multicolumn{4}{|c|}{ p-value ${ }^{1}$} \\
\hline & protected & conventional & & & & Type & Dose & TxC & AxCTL \\
\hline \multicolumn{5}{|c|}{ Dry matter } & 0.309 & NS & NS & NS & NS \\
\hline $0.5 \%$ & 23.22 & 23.17 & & \multirow{2}{*}{22.43} & & & & & \\
\hline $1.0 \%$ & 23.87 & 23.46 & & & & & & & \\
\hline \multicolumn{5}{|c|}{ Mineral matter (\% DM) } & 0.536 & NS & NS & NS & NS \\
\hline $0.5 \%$ & 7.46 & 7,70 & & \multirow{2}{*}{6.86} & & & & & \\
\hline $1.0 \%$ & 8,03 & 7,48 & & & & & & & \\
\hline \multicolumn{5}{|c|}{ Crude protein $(\% \mathrm{DM})$} & 0.642 & NS & $* *$ & $*$ & $* *$ \\
\hline $0.5 \%$ & $8.83 * \mathrm{aB}$ & $9.67 * \mathrm{aB}$ & & \multirow{2}{*}{3.88} & & & & & \\
\hline $1.0 \%$ & $14.64 * \mathrm{bA}$ & $15.46^{* \mathrm{bA}}$ & & & & & & & \\
\hline \multicolumn{5}{|c|}{ Ether extract (\% DM) } & 0.602 & $*$ & $*$ & NS & NS \\
\hline $0.5 \%$ & 0.75 & 0.46 & $0,61^{\mathrm{A}}$ & \multirow{3}{*}{0.59} & & & & & \\
\hline $1.0 \%$ & 1.27 & 0.77 & $1,02^{\mathrm{B}}$ & & & & & & \\
\hline Mean & $1.01 \mathrm{~b}$ & $0.62 \mathrm{a}$ & & & & & & & \\
\hline \multicolumn{5}{|c|}{ Neutral detergent fiber (\% DM) } & 0.360 & NS & NS & NS & $* *$ \\
\hline $0.5 \%$ & $46.91 *$ & $44.68^{*}$ & & \multirow{2}{*}{52.02} & & & & & \\
\hline $1.0 \%$ & $44.78^{*}$ & $44.35^{*}$ & & & & & & & \\
\hline \multicolumn{5}{|c|}{ Acid detergent fiber (\% DM) } & 0.428 & NS & NS & NS & $* *$ \\
\hline $0.5 \%$ & 25.46 & 24.74 & & \multirow{2}{*}{28.16} & & & & & \\
\hline $1.0 \%$ & 24.29 & $24.04 *$ & & & & & & & \\
\hline \multicolumn{4}{|c|}{ Lignin $(\% \mathrm{DM})$} & & 0.445 & NS & NS & NS & $* *$ \\
\hline $0,5 \%$ & 17.52 & 17.29 & & \multirow{2}{*}{19.60} & & & & & \\
\hline $1,0 \%$ & $16.07 *$ & $16.16^{*}$ & & & & & & & \\
\hline
\end{tabular}

${ }^{1}$ Type, effect of urea type; Dose, effect of urea dosage; TxC: interaction effect between type and dose of urea; AxCTL: effect of the additive compared to the control.

$*$ and $* *$ significant at the level of 5 or $1 \%$ significance respectively.

* Means followed by an asterisk differ from the control by Dunett's test $(\mathrm{p}<0.05)$. Means followed by different superscript uppercase letters $(\mathrm{A}, \mathrm{B})$ within the same column, and different superscript lower-case letters $\left({ }^{\mathrm{a}, \mathrm{b}}\right)$ within the same row, are significantly different by the $t$ test $(\mathrm{p}<0.05)$. SEM - standard error of the mean. 
Treatment of sugarcane silage with urea (conventional or protected) reduced the "a" fraction by $11.8 \%$ in relation to the control (mean of $44.07 \%$; Table 3 ). There was a significant interaction between dose and type of urea, with the highest average observed in sugarcane silage supplemented with $1 \%$ conventional urea. The inclusion of $0.5 \%$ urea decreased potential degradability of the DM compared with that of the control regardless of urea type. There was no interaction effect for fraction "b" ( $>>0.05)$. However, there were effects for both doses, with a higher average at the $0.5 \%$ dose and urea type, with a higher mean for protected urea. There was also a difference between the treatment with $0.5 \%$ protected urea and the control for fraction "b" $(p<0.05)$. For fraction "c", no difference was observed between treatments, with means of $2.2 \%$ per hour $(\mathrm{p}>0.05)$.

There was a significant interaction between concentrations and urea types for the potential degradability of dry matter (DM), with the highest average found after $1 \%$ urea, regardless of type. The inclusion of urea in the sugarcane silage increased the undegradable fraction of $\mathrm{DM}$ by $11.73 \%$ in relation to the control silage. There was a significant interaction between dose and urea type, with the highest average observed for $0.5 \%$ protected urea.

Table 3. Ruminal degradation parameters of dry matter of sugarcane silages supplemented with two types of urea and two concentrations.

\begin{tabular}{|c|c|c|c|c|c|c|c|c|c|}
\hline \multirow{2}{*}{ Concentrations } & \multicolumn{2}{|c|}{ Urea } & \multirow[b]{2}{*}{ Mean } & \multirow[b]{2}{*}{ Control } & \multirow[b]{2}{*}{ SEM } & \multicolumn{4}{|c|}{ p-value ${ }^{1}$} \\
\hline & protected & conventional & & & & Type & Dose & TxC & AxCTL \\
\hline \multicolumn{5}{|c|}{ Fraction "a", \% } & 0.190 & $* *$ & $*$ & $* *$ & $*$ \\
\hline $0.5 \%$ & $32.95 * \mathrm{Bb}$ & $39.02 * \mathrm{Ba}$ & & \multirow{2}{*}{44.07} & & & & & \\
\hline $1.0 \%$ & $41.38 * \mathrm{Ab}$ & $42.06 * \mathrm{Aa}$ & & & & & & & \\
\hline \multicolumn{5}{|c|}{ Insoluble fraction "b", \% } & 0.448 & $*$ & $*$ & NS & $*$ \\
\hline $0.5 \%$ & $24.00 *$ & 20.65 & $22.33^{\mathrm{A}}$ & \multirow{2}{*}{19.13} & & & & & \\
\hline $1.0 \%$ & 21.40 & 18.97 & $20.18^{\mathrm{B}}$ & & & & & & \\
\hline Mean & $22.70^{\mathrm{a}}$ & $19.81^{\mathrm{b}}$ & & & & & & & \\
\hline \multicolumn{5}{|c|}{ Potential degradability of "c", \% hour ${ }^{-1}$} & 0.741 & NS & NS & NS & NS \\
\hline $0.5 \%$ & 2.2 & 2.2 & & \multirow{2}{*}{2.5} & & & & & \\
\hline $1.0 \%$ & 2.2 & 2.2 & & & & & & & \\
\hline \multicolumn{5}{|c|}{ Potential degradability $\%$} & 0.241 & * & ** & * & * \\
\hline $0.5 \%$ & $56.96^{\mathrm{Bb} *}$ & $59.67^{\mathrm{Ba} *}$ & & \multirow{2}{*}{63.2} & & & & & \\
\hline $1.0 \%$ & $62.78^{\mathrm{Aa}}$ & $61.93^{\mathrm{Aa}}$ & & & & & & & \\
\hline \multicolumn{5}{|c|}{ Effective degradability, $\%$} & 0.141 & $*$ & * & $*$ & $*$ \\
\hline $0.5 \%$ & $40.34 \mathrm{~B}^{\mathrm{b} *}$ & $45.72^{\mathrm{Ba} *}$ & & \multirow{2}{*}{50.20} & & & & & \\
\hline $1.0 \%$ & $48.04 * \mathrm{Ab}$ & $49.20 * \mathrm{Aa}$ & & & & & & & \\
\hline \multicolumn{5}{|c|}{ Undegradable fraction, $\%$} & 0.298 & $*$ & ** & $*$ & $*$ \\
\hline $0,5 \%$ & $43.04 \mathrm{~A}^{\mathrm{a} *}$ & $40.32^{\mathrm{Ab} *}$ & & \multirow{2}{*}{36.79} & & & & & \\
\hline $1,0 \%$ & $37.22 \mathrm{~B}^{\mathrm{a}}$ & $38.06^{\mathrm{Ba}}$ & & & & & & & \\
\hline
\end{tabular}

${ }^{1}$ Type, effect of urea type; Dose, effect of urea dosage; TxC: interaction effect between type and dose of urea; AxCTL: effect of the additive compared to the control.

* and ** significant at the level of 5 or $1 \%$ significance respectively.

Means followed by an asterisk differ from the control by Dunett's test $(\mathrm{p}<0.05)$. Means followed by different superscript uppercase letters $(\mathrm{A}, \mathrm{B})$ within the same column, and different superscript lower-case letters $\left({ }^{\mathrm{a}}, \mathrm{b}\right)$ within the same row are significantly different by the $t$ test $(p<0.05)$. SEM - standard error of the mean. 


\section{Discussion}

Sugarcane has intrinsic characteristics, such as low buffering power and high solublecarbohydrate concentration, which allow adequate conservation, even with a DM content below $28 \%$.

Monteiro et al. (2011) suggested that $28 \% \mathrm{DM}$ is the minimum requirement for proper fermentation since the rapid drop in $\mathrm{pH}$ inhibits the development of undesirable microorganisms. The additives did not alter the DM content of the silages, which were all below $28 \%$. The absence of any effect of the additives can be explained by the low proportions of urea added to the silage, and the fact that they are deterioration-inhibiting and not absorbent additives (Castro Neto et al., 2008) (Table 1).

Even with DM values below those recommended for adequate fermentation, the $\mathrm{pH}$ values were all less than 4.1 , which is sufficient to restrict the development of undesirable microorganisms (Arriola et al., 2011; Ogunade et al., 2017). The low $\mathrm{pH}$ values of silage are due to the low buffer capacity of sugarcane, even when a relatively small amount of acid is produced during silage (Pedroso et al., 2014). However, the $\mathrm{pH}$ of the silage with $1 \%$ conventional urea was higher than the control, although within the limit mentioned above. The high $\mathrm{pH}$ observed on the $1 \%$ conventional urea treatment was associated with increased ammonia release compared to treatment with the same dose of protected urea. Additionally, the high $\mathrm{pH}$ raised the buffering power of the ensiled material, as ammonia absorbs $\mathrm{H}+$ ions present in the medium, neutralizes them, and retards the decrease of the $\mathrm{pH}$ (Ferreira et al., 2007) (Table 1).

Treatments with $1 \%$ urea showed higher values of $\mathrm{N}-\mathrm{NH} 3$ compared to $0.5 \%$ urea treatments. This increase in N-NH3 content is related to the transformation of urea to ammonia; the higher concentration of urea released higher amounts of N-NH3 in the medium. This result is consistent with the report of Freitas et al. (2017), who observed a linear increase in the percentage of N-NH3 with increasing urea concentrations in millet silage (Table 1).

With regard to urea type, protected urea presented the lowest N-NH3values. This is related to the polymers that cover urea molecules, reducing urease action on urea and controlling ammonia release into the medium. Lopes and Evangelista (2010) reported that ammonia originating from the urease action on urea has an inhibitory effect on yeast growth, thereby reducing DM losses in the silage. Thus, a better evaluation of the N-NH3 level must be made for sugarcane silage, since it can improve silage conservation when it does not exceed a maximum of $10 \%$, according to Costa et al. (2016).

The addition of urea, independently of concentration, reduced gas losses compared to the control treatment. This reduction was associated with the inhibition of breakdown of soluble carbohydrates to release carbon dioxide (Yuan et al., 2017), the main metabolic product related to gas losses. This inhibitory effect is attributed to ammonia production inside the silo, which inhibits fungal and yeast growth (Kung Jr. et al., 2000; Cao et al, 2014.). These microorganisms ferment soluble carbohydrates, producing ethanol, $\mathrm{CO} 2$, and volatile compounds that cause DM losses (McDonald et al., 1991). The addition of urea did not influence effluent losses; this is another source of nutrient loss as leaching of soluble compounds can occur, leading to a reduction in the nutritional value of silage (Gebrehanna et al., 2014).

The CP was higher in the silage with $1 \%$ urea $(15.05 \%)$ compared with the silage with $0.5 \%$ urea $(9.25 \%)$, which resulted from the greater addition of non-protein nitrogen in this treatment. Urea is a source of non-protein nitrogen, with $45 \% \mathrm{~N}$ for conventional urea and $39 \%$ for protected urea. This inclusion 
increases the total nitrogen content in silage, which is computed as CP.

Urea type and concentration had variable influences on the fibrous fraction of sugarcane silage compared to the control silage. All the silage treated with urea differed from the control in NDF content, suggesting that the released ammonia resulted in alkaline hydrolysis with partial solubilization of hemicellulose (Lopes and Evangelista, 2010; Carvalho et al., 2012). Another possible mechanism is that the greater preservation of non-fibrous carbohydrates promoted by the additive caused a dilution effect on NDF content (Jacovaci et al., 2017) (Table 2). Only the silage treated with $1 \%$ conventional urea showed difference with the control silage; this result may be associated with a higher release of ammonia, causing a more intense alkaline hydrolysis of this fraction.

Lignin content only differed from the control for the silage treated with $1 \%$ urea. Van Soest (1994) mentioned that during alkaline treatment, some lignin and silica could be dissolved in the process; so, a higher dose of urea might induce a higher rate of hydrolysis of these constituents.

There was an increase of the EE contents in the silages treated with either $1 \%$ conventional or protected urea. A similar result was reported by Silva et al. (2014a), who found an increase in EE content for sugarcane silage after 1\% urea treatment. With regard to urea type, an increase in EE values was observed in the silage treated with protected urea. This increase in EE content (Table 2) may be related to the coatings used in protected urea; these are soluble in organic solvents and are counted as lipids. Among the urea encapsulation techniques used by the industry, we can highlight the use of elemental sulfur, polymers, and waxes (Valderrama et al., 2014).

The highest degradability was observed in silage treated with either $1 \%$ protected or conventional urea. These treatments were associated with higher ammonia release, providing a higher rate of hemicellulose solubilization. According to Van Soest (1994), alkaline agents, such as urea, act on covalent ester-type bonds between lignin and hemicellulose to increase solubility of the fibrous fraction.

The use of urea in sugarcane silage decreases alcoholic fermentation and soluble carbohydrate losses and promotes quantitative gains due to lower gas losses (Vieira et al., 2017) and qualitative gains due to increased digestibility (Araki et al., 2017). However, in this study, urea reduced the effective degradability by $8.71 \%$ compared to silage without the additive. Other studies, such as that by Fortaleza et al. (2012), reported a similar result for sugarcane silage following the addition of $1 \%$ of urea. The latter report pointed out that the cause of this effect is unclear. Nevertheless, forage treatment with alkaline substances generally provides an increase in the effective degradability of DM (Rossi Junior and Schogor, 2006). Schmidt et al. (2007) compared sugarcane silage without additives or with $5 \%$ urea, showing that the DM in silage with urea had high effective degradability and NDF content was reduced to produce this high effective degradability.

In the present study, the NDF content also decreased in treated silages compared to the control, but there was no improvement in effective DM degradability. Schmidt et al. (2007) reported that qualitative variations of NDF fraction might influence degradability.

Based on this premise, together with technology advances and genetic improvements, new varieties of sugarcane for animal feed have been developed and made available in the market. Thus, variety IAC 86-2480 used in this study presents higher values of ruminal parameters when compared to variety RB72-454 used by Fortaleza et al. (2012). In these two varieties (IAC 86-2480 and RB72-454) no effect of urea inclusion on ensiling was observed with regard to effective degradability. However, a study on another 
variety at Instituto Agronômico do Paraná found that the addition of $1 \%$ urea in sugarcane silage increases effective degradability of DM to $15.36 \%$ (Rossi Junior and Schogor, 2006). A study with four sugarcane varieties (RB 855536, RB 765418, SP 80-1842, and SP 80-1816) observed variation in the effective degradability of DM and the readily soluble fraction, because the quality and structural arrangement of the fibers were different (Spínola et al., 2017). This variation in ruminal kinetic behavior using different varieties and additives has also been reported by Silva et al. (2014b).

With respect to ruminants, DM effective degradability of sugarcane silage tends to increase as the amount of ammonia in the silage rises. Ammonia is a source of nitrogen for fibrolytic and cellulolytic bacteria, and increased bacterial activity improves degradation of the fibrous fraction (Van Soest, 1994). This contribution of urea to the increase of nitrogen compounds is supported by the ammoniacal nitrogen and crude protein results. However, in the present study nitrogen increase was not used by ruminal bacteria since degradation rate of the insoluble fraction " $b$ " to fraction "c" was constant, at 2.2\% per hour. More studies are needed to elucidate the basis of this effect.

The use of protected or conventional urea at $1 \%$ of natural matter at the time of ensiling of sugarcane reduces losses by gases and improves the nutritional composition, with increase of crude protein (CP) content and reduction of fibrous fraction.

\section{Declarations}

\section{Acknowledgments}

The authors thank the people at Fundação de Amparo à Pesquisa do Estado de Minas Gerais (FAPEMIG).

\section{Funding}

This study was funded by the Coordenação de Aperfeiçoamento de Pessoal de Nível Superior - Brasil (CAPES) - Finance Code 001.

\section{Conflict of interest}

The authors declare they have no conflicts of interest with regard to the work presented in this report.

\section{Author contribution}

João Paulo Sampaio Rigueira, Ignácio Aspiazú and Vicente Ribeiro Rocha Júnior designed the project. Wagner Sousa Alves, Diego Lucas Soares de Jesus, Marielly Maria de Almeida Moura carried out the experiment. Flávio Pinto Monção determined the statistical model of the experiment and the data analysis. Wagner Alves Sousa carried out the writing of the manuscript. All authors provide critical feedback of the writing and editing.

\section{References}

Agricultural and Food Research Council - AFRC. Energy and protein requirements of ruminants. Walligford: CAB International, 1993.

Araki HMC, Oliveira ER, Gandra JR, Goes RHTB, Takiya CS, Jacaúna AG, Duan Orbach N. Association of Biological and Chemical Additives on Nutrient Composition, Total Losses, Microbiological and Fermentative Profile of Sugarcane Silage. Iran J Appl Anim Sci 2017; 07(4):577-584. http://ijas.iaurasht.ac.ir/article 535722 a278992fe189b7f4e8a68811d50510e4.pdf

Arriola KG, Kim SC, Adesogan AT. Effect of applying inoculants with heterolactic or homolactic and heterolactic bacteria on the fermentation and quality of corn silage. J Dairy Sci 2011; 94(3):1511-1516. DOI: https://doi.org/10.3168/jds.2010-3807 
Association of Official Agricultural Chemists - AOAC. Official methods of analysis. 13 ed. Washington: AOAC, 1980. 1015p.

Cao Y, Zang Y, Lv R, Takahashi T, Yoshida $N$, Yang $H$. Effects of adding urea on fermentation quality of pruned persimmon branch silage and its digestibility, preference, nitrogen balance and rumen fermentation in beef cattle. Anim Sci J 2014; 85(3):219-226. DOI: https://doi.org/10.1111/asj.12135

Carvalho BF, Ávila CLS, Pinto JC, Pereira MN, Schwan RF. Effects of propionic acid and Lactobacillus buchneri (UFLA SIL 72) addition on fermentative and microbiological characteristics of sugar cane silage treated with and without calcium oxide. Grass forage Scie 2012; 67:462-471. DOI: https://doi.org/10.1111/ j.1365-2494.2012.00863.x

Casali AO, Detmann E, Valadares Filho SC, Pereira JC, Cunha M, Detmann KSC, Paulino MF. Estimação de teores de componentes fibrosos em alimentos para ruminantes em saco de diferentes tecidos. R Bras Zootec 2009; 38(1):130-138. DOI: http://dx.doi.org/10.1590/S1516$\underline{35982009000100017}$

Castro Neto AG, Molina LR, Gonçalves LC, Jayme CG. Parâmetros de fermentação de silagens de cana-de-açúcar submetidas a diferentes tratamentos. Arq Bras Med Vet Zootec 2008: 60(5):1150-1156. DOI: http://dx.doi. org/10.1590/S0102-09352008000500017

Costa EF, Pires DADA, Moura MMA, Sales, ECJD, Rodrigues JAS, Rigueira JPS. Agronomic characteristics of sorghum genotypes and nutricional values of silage. Acta Sci Anim Sci 2016; 38(2):127-133. DOI: http://dx.doi. org/10.4025/actascianimsci.v38i2.29567

Detmann E, Souza MA, Valadares Filho SC, Quiroz AC, Berchielli TT, Saliba EOS, Cabral LS, Pina DS, Ladeira MM, Azevedo JAG. Métodos para análise de alimentos: Instituto Nacional de Ciência e Tecnologia de Ciência Animal, INCT. Viçosa, MG: Suprema. 2012. 214 p.
Ferreira DA, Gonçalves LG, Molina LR, Castro Neto AJ, Tomich TR. Características de fermentação da silagem de cana-de-açúcar tratada com ureia, zeólita, inoculante bacteriano e inoculante bacteriano/enzimático. Arq Bras Med Vet Zootec 2007; 59(2):423-33. DOI: http://dx.doi.org/10.1590/S0102-09352007000200024

Fortaleza APS, Silva LDF, Zackm E, Barbero RP, Ribeiro ELA, Pegoraro M, Santos LE, Mizubuti IY. Chemical composition and ruminal degradability of the sugar cane silage treated with chemical and bacterial additives. Semina: Ciênc Agrár 2012; 33(2):3341-3352. DOI: http://dx.doi. org/10.5433/1679-0359.2012v33n6Supl2p3341

Freitas PMDD, Carvalho GGPD, Santos EM, Araújo GGL, Oliveira JSD, Pires AJV, Maranhão CMA, Rodrigues TCGC, Pinto LFB. Qualitative parameters of pearl millet silage ammoniated with urea, at different compaction densities. Pesq Agropec Bras 2017; 52(8):679-689. DOI: ht t p://dx.doi.org/10.1590/s 0100 $\underline{204 \times 2017000800014}$

Gebrehanna MM, Gordon RJ, Madani A, VanderZaag AC, Wood JD. Silage effluent management: a review. J Environ Manage 2014(1); 143:113-122. DOI: https://doi.org/10.1016/j.jenvman.2014.04.012

Jacovaci FA, Jobim CC, Schmidt P, Nussio LG, Daniel JLP. A data-analysis on the conservation and nutritive value of sugarcane silage treated with calcium oxide. Anim Feed Sci Technol 2017; 225:01-07. DOI: https://doi.org/10.1016/j.anifeedsci.2017.01.005

Jobim CC. Nussio LG. Reis RA, Schmidt P. Avanços metodológicos na avaliação da qualidade da forragem conservada. R Bras Zootec 2007; 36 Suppl :101-119. DOI: http://dx.doi. org/10.1590/S1516-35982007001000013

Kung JrL, Stokes MR, Lin CJ. Silage additives. In: Buxton DR, Muck RE, Harrison JH, editors. Silage science and technology. American Society of Agronomy, Crop Science Society of America, Soil Science Society of America. Madison; 2003. p. 251-304. 
Kung JrL, Robinson JR, Ranjit NK, Chen JH, Golt CM, Pesek JD. Microbial populations, fermentation end-products, and aerobic stability of corn silage treated with ammonia or a propionic acid-based preservative. J Dairy Sci 2000; 83(3):1479-1486. DOI: https://doi.org/10.3168/jds.S0022$\underline{0302(00) 75020-X}$

Lopes J, Evangelista AR. Características bromatológicas, fermentativas e população de levedurasdesilagensdecana-de-açúcaracrescidas de ureia e aditivos absorventes de umidade. R Bras Zootec 2010; 39(5):984-991. DOI: http://dx.doi.org/10.1590/S1516$\underline{35982010000500007}$

McDonald P, Henderson AR, Heron SJE. The biochemistry of silage. 2.ed. Marlow: Chalcombe, 1991.

Monteiro IJG, Abreu JG, Cabral LS, Ribeiro MD, Reis RHP. Silagem de capim elefante aditivada com produtos alternativos. Acta Sci Anim Sci 2011; 33(4):347-352. DOI: http://dx.doi.org/10.4025/actascianimsci. v33i4.12629

Moreira JV, Pereira MLA, Azevedo ST, Signoretti RD, Siqueira GR, Pires AJV. Sugar cane fresh or ensiled with or without bacterial additive in diets for dairy cows. Acta Sci Anim Sci 2014; 36(4):385-391. DOI: http://dx.doi.org/10.4025/actascianimsci. $\underline{\mathrm{v} 36 \mathrm{i} 4.22475}$

Neter J, Wasserman W, Kutner MH. Applied linear statistical models. Regression, analysis of variance, and experimental designs. 2. ed. USA, Richard D. Irwin, Inc., 1985. 1127 p.

Nocek JE. In situ and other methods to estimate ruminal protein and energy digestibility: a review. J Dairy Sci 1988; 71(8):2051-2069. DOI: https://doi.org/10.3168/jds.S00220302(88)79781-7

Ogunade IM, Jiang Y, Kim DH, Cervantes AP, Arriola KG, Vyas D, Weinberg ZG,
Jeong KC, Adesogan AT. Fate of Escherichia coli O157: $\mathrm{H} 7$ and bacterial diversity in corn silage contaminated with the pathogen and treated with chemical or microbial additives. J dairy Sci 2017; 100(3):1780-1794. DOI: https://doi.org/10.3168/jds.2016-11745

Ørskov ER, McDonald I. The estimation of degradability in the rumen form incubation measurement weighted according to rate of passage. J Agric Sci 1979; 92(2):499-508. DOI: https://doi.org/10.1017/S0021859600063048

Pedroso AF, Pedroso AM, Júnior WB, de Sousa GB. Evaluation of sugarcane laboratory ensiling and analysis techniques. R Bras Zootec 2014; 43(4):169-174. DOI: http://dx.doi.org/10.1590/ $\underline{\text { S1516-35982014000400002 }}$

Rigueira JPS, Monção FP, Sales ECJ, Brant LMS, Pires DAA, Alves DD, Reis ST. Níveis de glicerina bruta na ensilagem de cana-de-açúcar: perdas e valor nutricional. B Ind Anim 2018; 74(4):308-316. DOI: https://doi.org/10.17523/bia.v74n4p319

Rossi Junior P, Schogor ALB. Degradabilidade in situ de cana-de-açúcar ensilada com uréia e milho em diferentes proporções. Arch Vet Sci 2006; 11(3):15-18. DOI: https://doi.org/10.5380/ avs.v11i3.7432

Roth APTP, Siqueira GR, Rabelo CHS, Härter CJ, Basso FC, Berchielli TT, Reis RA. Impact of days post-burning and lime as an additive to reduce fermentative losses of burned sugarcane silages. Anim Feed Sci Technol 2016; 216:68-80. DOI: https://doi.org/10.1016/j. anifeedsci.2016.03.010

Ruppel KA, Pitt RE, Chase LE, Galton DM. Bunker silo management and its relationship to forage preservation on dairy farms. J Dairy Sci 1995; 78(1):141-153. DOI: https://doi.org/10.3168/jds.S0022$\underline{0302(95) 76624-3}$ 
Schmidt P, Nussio LG, Zopollatto M, Ribeiro JL, Santos VP, Pires AV. Aditivos químicos ou biológicos na ensilagem de cana-de-açúcar. 2. Parâmetros ruminais e degradabilidade da matéria seca e das frações fibrosas. R Bras Zootec 2007; 36(5):1676-1684. DOI: http://dx.doi.org/10.1590/S 1516 $\underline{35982007000700028}$

Silva GWV, Rocha Júnior VR, Rocha WJB, Reis ST, Pires DAA, Antunes APS, Almeida Filho SHC, Oliveira LM, Caldeira LA, Souza, V. M. Degradabilidade in situ das silagens de variedades de cana-de açúcar com aditivos. Arch Zootec 2014b; 63(241):171-182. DOI: http://dx.doi.org/10.4321/S 0004 $\underline{05922014000100017}$

Silva WS, Santos, TMC, Cavalcanti Neto CC, Espíndola Filho AM, Silva SGM, Figueiredo AN, Melo BA. Características y estabilidad aeróbica de ensilajes de caña de azúcar, tratada con urea, $\mathrm{NaOH}$ y maíz. Pastos Forrajes 2014a; 37(2):182-190. http://www.redalyc.org/articulo. $\underline{\text { oa? } \mathrm{id}=269131791008}$

Spínola JEL, Reis ST, Sales ECJ, Monção FP, Rigueira JPS, Delvaux Júnior NA. Phenolic acids and ruminal parameters of different varieties of sugarcane in natura or ensiled. Acta Sci Anim Sci 2017; 39(1): 35-43. DOI: http://dx.doi.org/10.4025/actascianimsci. v39i1.31470

Statistical Analysis System Institute - SAS Institute. SAS/STAT 9. 2 User's guide. Cary: SAS Institute Inc., 2008.
Valderrama M, Buzetti S, Filho MCMT, Benett CGS, Andreotti M. Nitrogen fertilization in corn withureacoatedwithdifferentsources ofpolymers. Semina: Ciênc Agrár 2014; 35(2):659-670. DOI: https://doi.org/10.5433/1679-0359.2014v35n2p659

Van Soest PJ, Robertson JB, Lewis BA. Symposium: carbohydrate methodology, and nutritionalimplicationsindairy cattle. Methods for dietaryfiber, neutraldetergentfiber, and nonstarch polysaccharides in relation to animal nutrition. J Dairy Sci 1991; 74(10):3583-3597. DOI: https://doi.org/10.3168/jds.S0022$\underline{0302(91) 78551-2}$

Van Soest PJ. Nutritional ecology of the ruminant. 2 ed. New York: Cornell University Press, 1994. p. 476.

Vieira DA, Cezário AS, Valente TNP, Ribeiro JC, Santos WBR, Ferreira PRN. Evaluation of the addition of urea or calcium oxide $(\mathrm{CaO})$ on the recovery of dry matter of the by-product of sweet corn silage. J Agric Sci 2017; 9(9):141-148. DOI: $\underline{\text { https://doi.org/10.5539/jas.v9n9p141 }}$

Yuan X, Wen A, Dong Z, Desta ST, Shao, T. Effects of formic acid and potassium diformate on the fermentation quality, chemical composition and aerobic stability of alfalfa silage. Grass Forage Sci 2017; 72:833-839. DOI: $\underline{\text { https://doi.org/10.1111/gfs.12296 }}$ 